\title{
Incidence of potentially toxic concentrations of gentamicin in the neonate
}

\author{
A MULHALL, J DE LOUVOIS, AND R HURLEY \\ Queen Charlotte's Maternity Hospital and the Institute of Obstetrics and Gynaecology, \\ London
}

SUMMARY The incidence of putatively toxic serum concentrations and the factors influencing their occurrence were investigated in a study of 91 neonates receiving parenteral gentamicin twice daily at a dose of mean (SD) $5 \cdot 5(0 \cdot 1) \mathrm{mg} / \mathrm{kg}$ /day. Most neonates were preterm and of low birthweight. Serum concentrations, area under the curve (AUC), and clearance were calculated.

Potentially toxic trough concentrations $(>2 \mathrm{mg} / \mathrm{l})$ were recorded in 57 of $91(63 \%)$ neonates; 24 of these had trough concentrations greater than $3 \mathrm{mg} / \mathrm{l}$. These babies were of a significantly lower gestational age and were younger than the remainder of the population. Toxic trough concentrations were not accompanied by raised peak serum values. A wide variation in all pharmacokinetic variables was observed. Peak serum concentration was most highly correlated with dose, while trough concentration, AUC, and clearance were more dependent on postnatal age. Clearance of gentamicin decreased significantly with increasing serum urea and creatinine concentrations.

Preterm neonates in the first week of life are likely to develop potentially toxic serum concentrations when receiving the currently recommended dose of gentamicin (5-6 mg/ $\mathrm{kg} /$ day). To prevent accumulation the dosage interval may need to be increased to 18 hours in these babies.

Gentamicin is a valuable broad spectrum antibiotic and is extensively used for the treatment of serious sepsis in the newborn. It is ototoxic and nephrotoxic in the adult, ${ }^{1-3}$ and although toxicity in the neonate is not well documented, it would be reasonable to expect similar or more pronounced effects to those seen in adults. To avoid toxic effects it has been suggested that trough serum gentamicin concentrations should be below $2 \mathrm{mg} / \mathrm{l}$ and that peak values should not exceed $12 \mathrm{mg} / 1 .{ }^{45}$ Peak serum values less than $4 \mathrm{mg} / \mathrm{l}$ are considered subtherapeutic. ${ }^{6}$

Using these criteria, the incidence of putatively toxic and of subtherapeutic serum concentrations of gentamicin were determined in a study of the records of 64 neonates: a further 27 neonates were examined prospectively. Data on physiological and clinical factors that influence serum values and total body clearance of gentamicin were analysed.

Materials and methods

Study population. Ninety one neonates ( 52 boys and 39 girls) between 1 and 28 days of age were treated. Fifty one of 91 babies began treatment in week 1 of life. Their gestational age and birthweight were mean (SEM) $31(0 \cdot 5)$ weeks (range 25-40 weeks) and 1725 (100) g (range 700-4300 g) respectively. The dose of gentamicin was mean (SD) $5.5(0.1)$ $\mathrm{mg} / \mathrm{kg} /$ day divided 12 hourly and administered by either the intravenous or intramuscular route.

Specimen collection and assay of gentamicin. One hundred and thirty eight blood samples $(300 \mu l)$ were collected by heelprick immediately before (trough value) and one hour after (peak value) gentamicin. One hundred and thirty of 138 specimens were collected more than 48 hours after treatment began, that is at 'steady state'. Gentamicin concentration was determined on the day of receipt by plate diffusion technique ${ }^{7}$ using Klebsiella edwardsii (NCTC 10896) as assay organism.

Data analysis. Total body clearance and mean steady state serum concentration of gentamicin were determined from the peak and trough serum concentrations assuming an exponential decay between these two points and using a BASIC computer program to calculate the area under the curve (AUC). The following formulae were used: 


\begin{tabular}{|c|c|}
\hline & Dose \\
\hline$(\mathrm{ml} / \mathrm{min} / \mathrm{kg})$ & $\begin{array}{l}\text { Area under the concentration/ } \\
\text { time curve from } t=0 \text { to } t=12 \text { (AUC) }\end{array}$ \\
\hline Steady & $\begin{array}{l}\text { Area under the concentration } \\
\text { time curve from } t=0 \text { to } t=12 \text { (AUC) }\end{array}$ \\
\hline $\begin{array}{l}\text { oncentration } \\
(\mathrm{mg} / \mathrm{l})\end{array}$ & Dosage interval, $(t)$ \\
\hline
\end{tabular}

It was assumed that absorption was $90 \%$ complete at one hour after intramuscular injection and the true peak after intravenous injection is twice the one hour concentration after deduction of the trough concentration. ${ }^{89}$ The validity of calculating clearance using two points has been verified in a separate prospective study. ${ }^{9}$ The effects of sex, postnatal age, gestational age, birthweight, size and weight less than the 10th centile ( 21 babies), the presence of respiratory problems (33 babies), the administration of penicillin (70 babies) or theophylline ( 23 babies), and serum creatinine and urea concentrations ( 27 babies), on the serum values, clearance, and AUC of gentamicin were determined using Student's $t$ test and multiple regression analysis.

\section{Results}

Trough gentamicin concentrations greater than 2 $\mathrm{mg} / \mathrm{l}$ were observed in 57 of $91(63 \%)$ babies, but in only three were peak concentrations above the recommended maximum of $12 \mathrm{mg} / \mathrm{l}$. Of these 57 babies, 24 had trough concentrations greater than $3 \mathrm{mg} / \mathrm{l}$. Babies with potentially toxic trough values were of significantly lower gestational age $(\mathbf{P}=0.0001)$ than the rest of the population (Table 1); they were also younger. Dosage was reduced or stopped in 23 of 57 babies with high trough values, but no action was taken in 18, information was not available in 14 babies, and the remaining two babies died. Peak values less than $4 \mathrm{mg} / 1$ were recorded in five babies receiving $2 \cdot 7-5.0 \mathrm{mg} / \mathrm{kg} /$ day.

The mean serum concentrations and total body clearance of gentamicin in the 91 patients studied are shown in Table 2. A wide variation in both peak
Table 1 Comparison of postnatal age, gestational age, and dose in neonates with trough gentamicin concentrations above or below $2 \mathrm{mg} / \mathrm{l}$

\begin{tabular}{lclll}
\hline & $\begin{array}{l}\geqslant 2 \mathrm{mg} / \mathrm{l} \\
(n=57) \\
\text { Mean }(S E M)\end{array}$ & $\begin{array}{l}<2 \mathrm{mg} / \mathrm{l} \\
(n=34) \\
\text { Mean }(S E M)\end{array}$ & $t$ & $P$ \\
\hline $\begin{array}{c}\text { Postnatal age } \\
\text { (dys) }\end{array}$ & $9.3(0.8)$ & $11.5(1.3)$ & 1.5 & $\mathrm{NS}$ \\
$\begin{array}{c}\text { Gestational age } \\
\text { (wks) }\end{array}$ & $29.7(0.4)$ & $33.8(0.8)$ & 4.4 & 0.0001 \\
$\begin{array}{c}\text { Dose } \\
\text { (mg/kg/day) }\end{array}$ & $4.4(0.2)$ & $5.3(0.2)$ & 0.7 & $\mathrm{NS}$ \\
\hline NS $=$ not significant. & & & &
\end{tabular}

NS = not significant

Table 2 Peak and trough serum gentamicin concentrations and total body clearance in 91 neonates

\begin{tabular}{lllll}
\hline & No & Mean & $\begin{array}{l}\text { Standard } \\
\text { error }\end{array}$ & Range \\
\hline Peak serum concentration & 131 & 7.1 & 0.2 & $1 \cdot 1-14.0$ \\
$\begin{array}{c}\text { (mg/l) } \\
\text { Trough serum concentration } \\
(\mathrm{mg} / \mathrm{l})\end{array}$ & 135 & 2.5 & 0.1 & $<1.0-7.4$ \\
$\begin{array}{c}\text { Total body clearance } \\
(\mathrm{m} / \mathrm{min} / \mathrm{kg})\end{array}$ & 115 & 0.98 & 0.04 & $0.34-3.05$ \\
\hline
\end{tabular}

Table 3 Characteristics determining the serum values, $A U C$, and clearance of gentamicin in neonates

\begin{tabular}{lll} 
AUC, and clearance of gentamicin in neonates \\
\hline & $\begin{array}{l}\text { Significant } \\
\text { characteristics }\end{array}$ & $\begin{array}{l}\text { Coefficient of } \\
\text { multiple } \\
\text { correlation } \\
(\mathrm{mr})\end{array}$ \\
\hline Peak serum concentration & $\begin{array}{c}\text { Daily dose; } \\
\text { postnatal age }\end{array}$ & .4861 \\
Trough serum concentration & $\begin{array}{l}\text { Postnatal age; } \\
\text { daily dose; birthweight }\end{array}$ & .4808 \\
Steady state concentration & $\begin{array}{c}\text { Postnatal age; daily } \\
\text { dose; birthweight }\end{array}$ & .4468 \\
Area under the curve (AUC) & $\begin{array}{l}\text { Postnatal age; daily } \\
\text { dose; birthweight }\end{array}$ & .4518 \\
Total body clearance & $\begin{array}{c}\text { Postnatal age; } \\
\text { birthweight }\end{array}$ & .4282 \\
\hline
\end{tabular}

$* \mathbf{P}<0.03$.

AUC $=$ area under the concentration curve.

and trough concentrations was observed. Although peak serum values showed significant correlation $(r=+.3775 ; P<0.0001)$ with dosage, this was not the case for trough concentration.

Multiple regression analysis showed that postnatal age was the most important factor controlling

Table 4 Effect of gestational age on the pharmacokinetics of gentamicin in babies less than 7 days old

\begin{tabular}{|c|c|c|c|c|}
\hline & $\begin{array}{l}\text { Peak } \\
\text { concentration }(\mathrm{mg} / \mathrm{l}) \\
\text { Mean }(S E M)\end{array}$ & $\begin{array}{l}\text { Trough } \\
\text { concentration }(\mathrm{mg} / \mathrm{l}) \\
\text { Mean }(S E M)\end{array}$ & $\begin{array}{l}A U C \\
(m g / \min / m l)\end{array}$ & $\begin{array}{l}\text { Clearance } \\
(\mathrm{ml} / \mathrm{min} / \mathbf{k g})\end{array}$ \\
\hline $\begin{array}{l}\text { Preterm ( } \leqslant 37 \text { weeks' gestation) } \\
\text { No }\end{array}$ & $\begin{array}{l}7 \cdot 8(0 \cdot 34) \\
(41)\end{array}$ & $\begin{array}{l}2 \cdot 9(0.21) \\
(42)\end{array}$ & $\begin{array}{l}3 \cdot 7(0 \cdot 21) \\
(33)\end{array}$ & $\begin{array}{l}0.8(0.05) \\
(33)\end{array}$ \\
\hline $\begin{array}{l}\text { Term (>37 weeks' gestation) } \\
\text { No }\end{array}$ & $\begin{array}{l}5 \cdot 7(0.66) \\
(8)\end{array}$ & $\begin{array}{l}1 \cdot 5(0 \cdot 36) \\
(8)\end{array}$ & $\begin{array}{l}2 \cdot 7(0.46) \\
(8)\end{array}$ & $\begin{array}{l}1 \cdot 16(0 \cdot 11) \\
(8)\end{array}$ \\
\hline
\end{tabular}


the trough and steady state serum concentration, AUC, and clearance of gentamicin (Table 3). In the first week of life clearance was slower than thereafter $(P<0 \cdot 05)$. Gestational age was not so important, although in preterm babies during the first week of life serum values were higher and clearance slower than in term babies $(P<0.01$; Table 4$)$. These differences between term and preterm babies were not observed after the first week of life. In the 27 babies examined prospectively, gentamicin peak and trough values increased and clearance decreased with increasing serum urea and creatinine concentrations $(P=0.001)$. None of the following factors had any effect on the pharmacokinetic variables of gentamicin: sex, being more or less than the 10th centile (for birthweight, head circumference, or length), the presence or absence of respiratory distress syndrome, or the concurrent administration of penicillin or theophylline.

\section{Discussion}

The high proportion of potentially toxic trough serum values observed in this study is disturbing. The population most likely to develop toxic trough serum values are premature babies less than 1 week old. Gentamicin accumulation in these babies may be predicted by increasing serum creatinine or urea concentrations (even if these are within the normal range for neonates). Since babies with trough values more than $2 \mathrm{mg} / 1$ did not have raised peak values, dosage reduction may result in subtherapeutic peak values. To prevent accumulation, the dosage interval may be increased to 18 hours in premature babies during the first week of life while maintaining the same daily dose.

Other factors that may have influenced the development of toxic values of gentamicin had no effect in our population. We did not confirm the report $^{10}$ that the excretion of aminoglycoside is prolonged in babies with respiratory distress syndrome. Similarly, although penicillin reduces the excretion of chloramphenicol in the newborn, ${ }^{911}$ it did not affect gentamicin values in the present study. The suggestion that appropriate for gestational age babies have higher peak and trough serum concentrations than small for gestational age babies ${ }^{6}$ was also not confirmed in our study.

The ototoxicity and nephrotoxicity of gentamicin, which are well documented in the adult, ${ }^{512}$ have not been extensively studied in the neonate. Although early investigators ${ }^{13-15}$ found no evidence of acute renal toxicity or vestibular damage in neonates treated with gentamicin, recommended dosage schedules have since been increased from 3-4 to $5-6 \mathrm{mg} / \mathrm{kg} /$ day. Finitzo-Hieber and co-workers ${ }^{16}$ reported no sensorineural hearing loss or vestibular dysfunction attributable to gentamicin treatment $(5-6 \mathrm{mg} / \mathrm{kg} /$ day $)$ in 116 infants studied up to the age of four years. Nephrotoxic effects have been observed in 7 of 50 infants receiving $5 \mathrm{mg} / \mathrm{kg} /$ day of gentamicin or tobramycin; ${ }^{17}$ trough concentrations more than $2 \mathrm{mg} / \mathrm{l}$ were observed in 5 of 7 of these infants. These authors could not, however, determine the extent to which renal function was affected by other drugs and underlying disease.

Although many authors ${ }^{512}$ believe trough concentrations are most important in predicting toxicity, others suggest that peak values, or both peak and trough values are most useful. ${ }^{18} 19$ Steady state serum concentration or bioavailability (AUC) of gentamicin may be more closely related to the toxic effects of this drug. The volume of distribution of gentamicin is increased in the newborn ${ }^{92}$ and it is possible that intracellular penetration with subsequent slow release may occur in young neonates. How this may influence the toxicity of gentamicin in the neonate is unknown. The hearing and vestibular function of the babies in the present study are currently under examination and the association between any toxicity observed and the serum values and bioavailability of gentamicin will be determined.

We thank Dr D R Harvey and Dr R Dinwiddie, consultant paediatricians at Queen Charlotte's Maternity Hospital, for permission to study their patients.

\section{References}

1 Hewitt WL. Gentamicin toxicity in perspective. Postgrad Med J 1974;50(Suppl 7):55-9.

2 Mawer GE, Ahmad R, Dobbs SM, McGough JG, Lucas SB, Tooth JA. Prescribing aids for gentamicin. Br J Clin Pharmacol 1974;1:45-50.

${ }^{3}$ Gailiunas P, Jr, Dominguez-Moreno M, Lazarus JM, Lowrie EG, Gottlieb MN, Merrill JP. Vestibular toxicity of gentamicin; incidence in patients receiving longterm hemodialysis therapy. Arch Intern Med 1978;138:1621-4.

4 Jackson GG, Arcieri G. Ototoxicity of gentamicin in man: a survey and controlled analysis of clinical experience in the United States. J Infec Dis (Suppl) 1971; 124:S130-7.

5 Dahlgren JG, Anderson ET, Hewitt WL. Gentamicin blood levels: a guide to nephrotoxicity. Antimicrob Agents Chemother 1975;8:58-62.

- Assael BM, Gianni V, Marini A, Peneff P, Sereni F. Gentamicin dosage in preterm and term neonates. Arch Dis Child 1977;52:883-6.

7 Broughall JM. Aminoglycosides. In: Reeves DS, Phillips I, Williams JD, Wise R, eds. Laboratory methods in antimicrobial chemotherapy. London: Churchill Livingstone, 1978:194-207.

8 Dobbs SM, Mawer GE. Intraveneus injection of gentamicin and tobramycin without impairment of hearing. J Infect Dis (Suppl) 1976;134:S114-7.

9 Mulhall AB. Antibiotic treatment in the newborn; some pharmacological aspects. PhD Thesis, University of London; 1982.

10 Myers MG, Roberts RJ, Mirhij NJ. Effects of gestational age, birthweight and hypoxemia on pharmacokinetics of 
amikacin in serum of infants. Antimicrob Agents Chemother 1977;11:1027-32.

11 Windorfer A, Jr, Pringsheim W. Studies on the concentrations of chloramphenicol in the serum and cerebrospinal fluid of neonates, infants and small children. Reciprocal reactions between chloramphenicol, penicillin and phenobarbitone. Eur J Pediatr 1977;124:129-38.

12 Schentag JJ, Cumbo TJ, Jusko WJ, Plaut ME. Gentamicin tissue accumulation and nephrotoxic reactions. JAMA 1978;240:2067-9.

13 Riley HD, Jr, Rubio T, Hinz W, Nunnery AW, Englund J. Clinical and laboratory evaluation of gentamicin in infants and children. J Infec Dis (Suppl) 1971;124: S236-46.

14 Klein JO, Herschel M, Therakan RM, Ingall D. Gentamicin in serious neonatal infections: absorption, excretion and clinical results in 25 cases. J Infec Dis (Suppl) 1971; 124:S224-31.

15 McCracken GH, Jr, Chrane DF, Thomas ML. Pharmacologic evaluation of gentamicin in newborn infants. J Infect Dis (Suppl) 1971;124:S214-23.

16 Finitzo-Hieber T, McCracken GH, Jr, Roeser RJ, Allen DA, Chrane DF, Morrow J. Ototoxicity in neonates treated with gentamicin and kanamycin: results of a four-year controlled follow-up study. Pediatrics $1979 ; 63: 443-50$.

17 Itsarayoungyuen S, Riff L, Schauf V, Hamilton L, Otrembiak J, Vidyasagar D. Tobramycin and gentamicin are equally safe for neonates: results of a double blind randomized trial with quantitative assessment of renal function. Pediatric Pharmacology 1982;2:143-55.

18 Bock BV, Edelstein PH, Meyer RD. Prospective comparative study of efficacy and toxicity of netilmicin and amikacin. Antimicrob Agents Chemother 1980;17:217-25.

19 Smith CR, Maxwell RR, Edwards CQ, Rogers JF, Lietman PS. Nephrotoxicity induced by gentamicin and amikacin. Johns Hopkins Med J 1978;142:85-90.

20 Milner RDG, Ross J, Froud DJR, Davis JA. Clinical pharmacology of gentamicin in the newborn infant. Arch Dis Child 1972;47:927-32.

Correspondence to Dr A Mulhall, Department of Microbiology, Queen Charlotte's Maternity Hospital, Goldhawk Road, London W6 0XG.

Received 21 June 1983

\section{Commentary}

\section{G RYLANCE}

\section{The Children's Hospital, Birmingham}

The authors draw attention to the incidence of potentially toxic gentamicin concentrations in the newborn. They point out that toxicity in the neonate is not well documented and it is important to stress this. The publication of this report, and others like it, is apt to substantiate and give further credence to the belief that aminoglycoside oto- and renal toxicity are likely and clearly established adverse effects in newborn practice. This is not the case and there is little evidence to suggest that the use of trough values below $2 \mathrm{mg} / \mathrm{l}$ and peak values below $12 \mathrm{mg} / \mathrm{l}$ are appropriate guidelines in newborns, infants, or children. Indeed, the manipulation of dosing to produce concentrations conforming with these values may so necessitate extension of the dose interval that efficacy is compromised. For the present, the major indication for monitoring values is to determine whether values clearly above the minimal inhibitory concentration of the likely causative organism are reached.

The results of a large North American study on adverse effects in newborns is expected shortly. Until this time and the time when further appropriate and definitive data are available, it seems reasonable to monitor aminoglycoside values as in this paper, particularly to show expected efficacious concentrations. A cautionary approach to the interpretation of values commonly considered to be toxic is, however, suggested. 